Rafae Michalowski ${ }^{1}$

\title{
Uwagi o prawie pierwokupu właściciela nieruchomości rolnej graniczącej ze sprzedawaną nieruchomością rolną w ustawie o kształtowaniu ustroju rolnego z dnia 5 sierpnia 2015 r.
}

Ustawa o kształtowaniu ustroju rolnego z dnia 5 sierpnia 2015 r. ${ }^{2}$ (dalej: u.k.u.r.) przewiduje szereg istotnych ograniczeń $\mathrm{w}$ obrocie nieruchomościami rolnymi, w tym całkowicie nowe - nieobecne w ustawie z dnia 11 kwietnia 2003 r. o kształtowaniu ustroju rolnego. ${ }^{3}$ Utrzymano $\mathrm{w}$ kształcie zbliżonym do dotychczas obowiązującego uregulowania, ustawowe prawo pierwokupu przysługujące dzierżawcom, a także Agencji Nieruchomości Rolnych. Podkreślenia wymaga to, że ustawodawca nie modyfikuje w żaden sposób prawa pierwokupu współwłaściciela nieruchomości rolnej, o którym mowa w art. 166 Kodeksu cywilnego.

Novum stanowi uregulowanie zawarte w art. 9 ust. 2 ustawy, zgodnie z którym w przypadku braku uprawnionego do pierwokupu dzierżawcy, albo niewykonania tego prawa, prawo pierwokupu przysługuje z mocy ustawy rolnikowi indywidualnemu będącemu właścicielem nieruchomości rolnej graniczącej ze sprzedawaną nieruchomością, a jeżeli ten warunek spełnia więcej niż jeden właściciel, prawo pierwokupu w pierwszej kolejności może wykonać ten, którego wskaże sprzedający nieruchomość rolną.

Należy sądzić, że ten lapidarny przepis stanowił będzie bardzo istotne w ramach regulacji pierwokupu ustawowego - praktycznie ograniczenie w obrocie nieruchomościami rolnymi, w istocie o znacznie większym znaczeniu niż prawo pierwokupu przysługujące dzierżawcy, współwłaścicielowi czy też Agencji Nieruchomości Rolnych. Pod rządami ustawy z dnia 11 kwietnia 2003 r. ANR nie korzystała $\mathrm{z}$ tego uprawnienia w stopniu, który czyniłby z niego znaczący w praktyce obrotu instrument prawny. ${ }^{4}$ Istotne problemy ze stosowaniem art. 9 ust. 2 u.k.u.r. będą

Uniwersytet w Białymstoku.

Dz.U. z 2015 r. poz. 1433. Ustawa wchodzi w życie z dniem 1 stycznia 2016 r.

Ustawa z dnia 11 kwietnia 2003 r. o kształtowaniu ustroju rolnego (Dz.U. z 2012 r. poz. 803).

Zgodnie z danymi zawartymi w Raporcie z działalności Agencji Nieruchomości Rolnych (ANR) na Zasobie Własności Rolnej Skarbu Państwa w 2014 r. ANR złożyła oświadczenia o wykonaniu na podstawie obowiązujących 
zapewne wynikały stąd, że nieraz możemy mieć do czynienia z nieruchomościami o nieuregulowanym stanie prawnym, w odniesieniu do których co najmniej znacząco utrudnione będzie określenie, kto jest ich właścicielem i tym samym umożliwienie wykonania prawa pierwokupu uprawnionemu, w tym zadośćuczynienie obowiązkowi zawiadomienia właściciela o przysługującym prawie pierwokupu, bez czego nie można sprzedać nieruchomości osobie trzeciej. Problem ten zostaje tu jedynie zasygnalizowany, a dalsze rozważania ograniczają się zasadniczo do dogmatycznej analizy nowej regulacji prawnej.

Przepis art. 9 ust. z u.k.u.r. rozstrzyga, że prawo pierwokupu przysługuje właścicielowi nieruchomości sąsiedniej posiadającemu status rolnika indywidulanego. Widać tu zasadniczą różnicę konstrukcyjną w stosunku do uregulowania pierwokupu dzierżawcy, w przypadku którego mowa jest o tym, że nabywana nieruchomość wchodzić ma w skład prowadzonego przez uprawnionego z tytułu pierwokupu gospodarstwa rodzinnego. Wyjaśnienie relacji zachodzących między pojęciami gospodarstwo rodzinne - rolnik indywidualny zostało dokonane wyczerpująco w doktrynie na tle art. 5 oraz 6 u.k.u.r. z 2003 r. ${ }^{5}$ Pod rządami nowych przepisów aktualne są sformułowane wcześniej w literaturze uwagi w tym zakresie, stąd w tym miejscu właśnie do nich należy się odwołać.

W szczególności należy wskazać, że norma 300 ha użytków rolnych zawarta $\mathrm{w}$ definicji gospodarstwa rodzinnego odnosi się do konkretnej jednostki produkcyjnej - chodzi o grunty, które stanowią bądź mogą stanowić zorganizowaną całość w jej ramach. Co do normy obszarowej zawartej w definicji rolnika indywidualnego, to chodzi o grunty będące własnością (dzierżawione, w użytkowaniu wieczystym, w posiadaniu samoistnym) danej osoby abstrahując od ich usytuowania względem siebie, a więc, niezależnie od tego, czy mogą tworzyć zorganizowaną jedną całość gospodarczą czy też są położone względem siebie w taki sposób, że jest to wykluczone. Nie jest tym samym istotne, w skład ilu gospodarstw rolnych owe grunty mogą wchodzić.

Zgodnie z art. 9 ust. 2 dla powstania uprawnienia do skorzystania z pierwokupu przez właściciela nieruchomości graniczącej ze sprzedawaną wystarczy, aby nieruchomość nabywał w ten sposób rolnik indywidualny. Ustawodawca nie nawiązuje do kategorii gospodarstwa rodzinnego określając jego przesłanki. W szczególno-

wówczas przepisów oświadczenia o wykonaniu uprawnień z tytułu pierwokupu i prawa nabycia w 9 przypadkach. W związku z obowiązującym od dnia 1 stycznia 2016 r. art. 20 ust. 5d ustawy z dnia 19 października 1991 r. o gospodarowaniu nieruchomościami rolnymi Skarbu Państwa (Dz.U. z 2015 r. poz. 1014 ze zm.) w planie finansowym Zasobu Własności Rolnej Skarbu Państwa 30\% wydatków przeznacza się na realizację zadań związanych z wykonywaniem prawa pierwokupu oraz uprawnienia, o którym mowa w art. 10 u.k.u.r. (prawa nabycia), co pozwala oczekiwać, że ANR będzie intensywniej niż dotychczas korzystała z tych uprawnień.

$5 \quad$ Zob. Z. Truszkiewicz, Przeniesienie własności nieruchomości rolnej w świetle ustawy o kształtowaniu ustroju rolnego (część II), „Rejent” 2003, nr 11, s. 114 i nast., P. Czechowski, P. Wieczorkiewicz, Problemy ingerencji prawnej w swobodę obrotu nieruchomościami rolnymi w ustawie o kształtowaniu ustroju rolnego i jej wpływ na interpretację ustawodawstwa krajowego, „Studia luridica Agraria” 2005, t. V, s. 39-40. 
ści ustawodawca nie rozstrzyga wyraźnie kwestii, czy w wyniku nabycia w drodze wykonania prawa pierwokupu gruntu przez właściciela nieruchomości graniczącej ze sprzedawaną - rolnika indywidulanego powinno nastąpić powiększenie gospodarstwa rodzinnego nabywcy. Językowe brzmienie art. 9 ust. 2 in principio uzasadnia interpretację, zgodnie z którą w wyniku skorzystania z prawa pierwokupu przez uprawnionego rolnika indywidualnego nie musi nastąpić nabycie własności nieruchomości, któraby weszła w skład gospodarstwa rodzinnego nabywcy. Natomiast ustawodawca odróżnia takie zdarzenia, jak ,nabycie przez rolnika indywidualnego” (art. 9 ust. 2 u.k.u.r.) od ,nabycia przez rolnika indywidualnego na powiększenie gospodarstwa rodzinnego" i nie wydaje się, abyśmy mieli do czynienia jedynie z obojętną normatywnie odmiennością w sposobie ujęcia językowego tych zwrotów bez zmiany ich znaczenia. Wniosek ten uzasadnia brzmienie art. 9 ust. 6 pkt 1 u.k.u.r. Przykładowo, rolnik indywidualny prowadzący gospodarstwo rodzinne w województwie podlaskim i będący jednocześnie właścicielem położonego w innej części Polski gruntu rolnego graniczącego ze sprzedawaną nieruchomością rolną, będzie mógł skorzystać z uprawnienia wskazanego w art. 9 ust. 2, nawet jeśli sam nie wykorzystuje tego gruntu do prowadzenia działalności rolniczej (nawet w ramach gospodarstwa nie posiadającego przymiotu gospodarstwa rodzinnego). Co więcej, w świetle literalnego brzmienia art. 9 ust. 2 u.k.u.r. prawo pierwokupu przysługuje mu także wtedy, gdy grunt będący jego własnością względnie trwale, na podstawie wieloletniej umowy dzierżawy wykorzystuje inna osoba mająca status rolnika indywidualnego prowadzącego gospodarstwo rodzinne zorganizowane na dzierżawionym gruncie. Może być tak, że względem dzierżawionego gruntu w powyżej zarysowanej sytuacji to dzierżawcy przysługiwałoby prawo pierwokupu na podstawie art. 9 ust. 1 u.k.u.r. (gdyby właściciel go sprzedawał), gdy właścicielowi owego gruntu (wydzierżawiającemu) - jeśli jest rolnikiem indywidualnym - w warunkach określonych przez art. 9 ust. 2 u.k.u.r. przysługiwać będzie równolegle prawo pierwokupu co do gruntu z nim graniczącego (gdyby grunt sąsiedni był sprzedawany). Prawo pierwokupu z art. 9 ust. 2 nie jest konstrukcyjnie, bezpośrednio powiązane z prowadzeniem działalności rolniczej, jeśli patrzeć na to przez pryzmat rzeczywistego sposobu wykorzystania gruntu, ze względu na który rolnikowi indywidualnemu przysługuje prawo pierwokupu (gdyż jako że nie musi wchodzić w skład jego gospodarstwa rodzinnego, więc w ogóle nie musi być eksploatowany rolniczo przez właściciela - rolnika indywidualnego ani żadną inną osobę). Prowadzenie działalności rolniczej jest związane z uprawnieniem z art. 9 ust. 2 jedynie pośrednio przez osobę rolnika indywidulanego, a więc osobę prowadzącą gospodarstwo - przysługuje ono wszak temu, kto prowadzi działalność rolniczą w gospodarstwie rodzinnym, ale niekoniecznie obejmującym nieruchomość, której własność czyni uprawnionym z tytułu pierwokupu z art. 9 ust. 2 u.k.u.r. Oczywiście należy przypuszczać, że w typowej sytuacji korzystać z wynikającego z tego przepisu pierwokupu będzie rolnik indywidualny prowadzący gospodarstwo rodzinne tam zorganizowane 
i w wyniku nabycia nieruchomości powiększane będzie gospodarstwo rodzinne, ale ów skutek nie jest konstytutywną przesłanką wskazaną w art. 9 ust. 2 warunkującą skuteczne wykonanie tego uprawnienia. Takie ujęcie, jak należy domniemywać, pozwalać ma w intencji prawodawcy przede wszystkim na relatywnie szerokie ograniczenie możliwości nabywania gruntów rolnych przez osoby „z zewnątrz” - nie związane w jakiś sposób z terenem, na którym znajduje się zbywana nieruchomość.

Bez znaczenia dla zastosowania art. 9 ust. 2 u.k.u.r. pozostaje, jaką powierzchnię ma nieruchomość, która ma zostać nabyta w drodze wykonania prawa. Obojętna dla zastosowania art. 9 ust. 2 jest też powierzchnia nieruchomości będącej własnością uprawnionego rolnika, granicząca ze zbywaną nieruchomością, a ze względu na którą powstaje prawo pierwokupu tam uregulowane. W szczególności przepisy nie ustanawiają dla żadnej z nich minimalnej powierzchni. Norma 1 ha użytków rolnych jest przez prawodawcę powiązana definicyjnie (zob. art. 2 pkt 2 u.k.u.r.) z powierzchnią użytków rolnych gospodarstwa rolnego w rozumieniu przepisów u.k.u.r. Skoro tak, to w jego skład mogą wchodzić grunty o dowolnej powierzchni, byleby w sumie obejmowały co najmniej 1 ha użytków rolnych. Jedynie prawo pierwokupu przysługujące Agencji Nieruchomości Rolnych z art. 9 ust. 3 jest ograniczone do gruntów o minimalnej powierzchni 1 ha użytków rolnych.

O ile już na podstawie nieskomplikowanych zabiegów interpretacyjnych dochodzi się do dość oczywistego wniosku o braku minimalnej normy obszarowej nieruchomości, która może być nabyta w wykonaniu prawa pierwokupu z art. 9 ust. 2 u.k.u.r., to bardziej problematyczna kwestia łączy się z określeniem, czy nabywając przez wykonanie prawa pierwokupu nieruchomość można przekroczyć maksymalną normę 300 ha użytków rolnych, o której mowa w art. 4 ust. 1 u.k.u.r. Wątpliwości w tym względzie są o tyle uzasadnione, że w przepisach wskazujących przypadki, w których prawo pierwokupu jest wyłączone - w art. 9 ust. 6 pkt 1 i 3 u.k.u.r. - prawodawca wprost odwołuje się do normy 300 ha użytków rolnych. Jednak - jeśli chodzi o przypadek z pkt 1 ust. 6 art. 9 u.k.u.r. należy wskazać na daleko idącą nieudolność prawodawcy przy określeniu zawartej w nim normy obszarowej. W tym przepisie prawodawca określa wprost, że w wyniku nabycia nieruchomości na powiększenie gospodarstwa rodzinnego nie może zostać przekroczona norma 300 ha użytków rolnych, o której mowa w art. 3 ust. 1 pkt 2 u.k.u.r. definiującym gospodarstwo rodzinne, gdy równolegle art. 9 ust. 7 definiuje powiększenie gospodarstwa rodzinnego jako powiększenie tej jednostki produkcyjnej wskazując również na ten sam pułap obszarowy wprost, bez odesłania do art. 3 ust. 1 pkt 2 . Mimo że te dwa przepisy zakreślając 300-hektarowy limit użytków rolnych gospodarstwa rodzinnego po jego powiększeniu zawierają inne zwroty dla określenia tej normy obszarowej, to nie powinno budzić wątpliwości, że mamy w obu przypadkach do czynienia ze wskazaniem na tę samą normę obszarową, a więc w istocie jest to superfluum. Przy tego rodzaju oczywistej niefrasobliwości prawodawcy można powziąć wątpli- 
wość, czy nieujęcie w art. 9 ust. 2 wymogu, aby grunty już będące własnością (oraz dzierżawione, pozostające w użytkowaniu wieczystym jak i w posiadaniu samoistnym rolnika indywidulanego wraz z nowo nabywanymi jest celowym rozwiązaniem i czy należy na podstawie porównania do przepisów, w których wyraźnie przewidziano normę maksymalną wyciągać adekwatne językowo wnioski interpretacyjne. Samo językowe znaczenie zwrotu „nabycie przez rolnika indywidulanego” nie uzasadnia konstatacji, że w wyniku nabycia nowemu właścicielowi wciąż ma przysługiwać, jak to było przed wykonaniem prawa pierwokupu, przymiot rolnika indywidualnego. Wydaje się więc, że wnioskowanie, iż ustawodawca z rozmysłem nie wprowadził ograniczenia obszarowego w tym przepisie, jest wystarczająco mocno uzasadnione już na gruncie systematyki u.k.u.r. oraz reguł wykładni językowej.

Pewne wątpliwości mogą się pojawić w przypadku, gdy mamy do czynienia z kilkoma uprawnionych właścicielami nieruchomości graniczących z nieruchomością sprzedawaną i co najmniej jeden z nich jest właścicielem dwóch albo więcej takich nieruchomości. Ten stan nie uprzywilejowuje takiego właściciela i nie ma wpływu na określenie kolejności, w jakiej może być złożone oświadczenie o wykonaniu prawa pierwokupu przez uprawnionych. Niezależnie od tego, czy dana osoba jest właścicielem jednej czy też kilku nieruchomości graniczących ze sprzedawaną, uprawnienie to można wykonać tylko raz, w kolejności wyznaczonej przez właściciela sprzedawanej nieruchomości, a nie wielokrotnie - tyle razy ilu nieruchomości graniczących ze sprzedawaną jest właścicielem. Nacisk należy bowiem położyć nie na liczbę nieruchomości będących własnością uprawnionego rolnika indywidualnego, ale, w tej akurat kwestii, istotny jest aspekt podmiotowy - uprawnienie przysługuje rolnikowi indywidualnemu ze względu na to, że jest właścicielem nieruchomości graniczącej ze sprzedawaną. Zresztą absurdalne, nie do pogodzenia z elementarnymi zasadami racjonalności byłoby przyznanie możliwości wykonywania prawa pierwokupu więcej niż jeden raz przez tę samą osobę tyle razy, ilu nieruchomości graniczących ze zbywaną jest właścicielem.

Przepis art. 9 ust. 2 u.k.u.r. przewiduje, że w razie gdyby uprawniony z tytułu pierwokupu był więcej niż jeden rolnik indywidualny, w pierwszej kolejności może wykonać je ten, którego wskaże sprzedający. Przepis ten w sposób nie dość precyzyjny określa sposób rozstrzygnięcia kolizji w pierwokupie kilku właścicieli gruntów graniczących ze sprzedawaną nieruchomością. Opierając się na jego literalnym znaczeniu, można utrzymywać, że wynika z niego jedynie, że w razie gdy jest kilku uprawnionych, tylko jeden $\mathrm{z}$ nich wskazany przez sprzedającego może w pierwszej kolejności złożyć oświadczenie o wykonaniu prawa pierwokupu. Ustawa nie rozstrzyga natomiast wprost, jak należy, przy kilku osobach uprawnionych, wykonać prawo pierwokupu w sytuacji, gdy wskazany przez sprzedającego właściciel nieruchomości sąsiedniej nie skorzysta z prawa pierwokupu. 
Wypada zauważyć, że w toku prac w Sejmie nad projektem ustawy o kształtowaniu ustroju rolnego proponowano, aby w pierwszej kolejności mógł je wykonać właściciel nieruchomości graniczącej z nieruchomością sprzedawaną, których granica jest najdłuższa. ${ }^{6} \mathrm{I}$ w tej wersji art. 9 ust. 2 projektu u.k.u.r. nie było definitywnie przesądzone, jak rozstrzygać kolizję uprawnionych w razie, gdy właściciel nieruchomości o najdłuższej granicy nie skorzysta ze swojego uprawnienia. Jednak takie ujęcie uzasadniało konstatację, że hierarchię uprawnionych ocenia się po porostu mając na uwadze długość granicy poszczególnych nieruchomości. Projektowana wersja art. 9 ust. 2 u.k.u.r. nie byłaby jednak zbyt fortunnym rozwiązaniem, ponieważ takie uregulowanie wymagałoby dokonywania pomiarów długości granicy nieruchomości dokonywanej w związku z zawarciem umowy sprzedaży aktualizującej pierwokup właściciela graniczącej nieruchomości. Dane dotyczące długości granicy nieruchomości nie są natomiast danymi podlegającymi ujawnieniu w ewidencji gruntów i budynków, stąd nie można by z nich skorzystać w tej kwestii określając, kto z właścicieli nieruchomości graniczących może wykonać prawo pierwokupu w pierwszej kolejności. ${ }^{7}$

$\mathrm{Z}$ tego zapewne powodu ostatecznie kryterium długości granicy zostało zastapione przez kryterium wskazania przez właściciela sprzedawanej nieruchomości osoby uprawnionej do wykonania prawa pierwokupu w pierwszej kolejności. Niezależnie od oceny, czy taki wariant przyczynia się do realizacji celów ustawy wymienionych $\mathrm{w}$ art. 1 u.k.u.r. (co do czego można mieć uzasadnione wątpliwości), z pewnością jest to rozwiązanie czytelne, nie łączy się też z żadnymi kosztami związanymi z określeniem osoby mogącej wykonać swoje prawo w pierwszej kolejności. Jednak ustawodawca formułując ów przepis nie rozwiązał wszystkich wątpliwości, związanych z równoległym przysługiwaniem pierwokupu kilku sąsiadom - rolnikom indywidualnym. Najistotniejsza wątpliwość dotyczy tego, że ustawodawca nie określa wprost niczego ponad to, że sprzedawca dokonuje wskazania jednego uprawnionego, a poza zakresem wynikającego z literalnego odczytania art. 9 ust. 2 in fine pozostają stany faktyczne, w których osoba mogąca wykonać prawo pierwokupu w pierwszej kolejności nie czyni tego. Powstaje zatem wątpliwość, w jaki sposób rozwiązać kolizję prawa pierwokupu kilku sąsiadów - rolników indywidualnych w przypadku, gdy wskazany przez sprzedawcę w pierwszej kolejności uprawnienia swego nie wykonuje.

Najrozsądniejszym rozwiązaniem wydaje się przyjęcie, że sprzedawca powinien od razu, w treści warunkowej umowy sprzedaży zawartej z osobą trzecią okre-

Zob. Sprawozdanie z dnia 17 czerwca 2015 r. podkomisji nadzwyczajnej do rozpatrzenia poselskiego projektu ustawy o kształtowaniu ustroju rolnego (druk nr 3109), www.sejm.gov.pl (data dostępu: 5.10.2015 r.). Zgodnie z art. 20 ust. 1 pkt 1 ustawy Prawo geodezyjne i kartograficzne (Dz.U. z 2015 r. poz. 520) w odniesieniu do gruntów danymi ewidencyjnymi są dane dotyczące ich położenia, granic, powierzchni, rodzajów użytków gruntowych oraz ich klas bonitacyjnych, oznaczenia ksiąg wieczystych lub zbiorów dokumentów, jeżeli zostały założone dla nieruchomości, w skład której wchodzą grunty. 
ślić kolejność, w której prawo pierwokupu mogą wykonać wszyscy uprawnieni, nikogo z nich nie pomijając. W takiej sytuacji uprawnieni powinni być informowani o możliwości wykonania prawa pierwokupu w kolejności wskazanej przez sprzedawcę, sukcesywnie jeden po drugim po tym, kiedy uprzywilejowany w pierwszej i dalszej kolejności nie wykona swojego prawa w terminie albo oświadczy, że nie ma zamiaru korzystać z prawa pierwokupu. Taka interpretacja wydaje się najlepiej oddawać intencje prawodawcy, który wyraźnie wskazał na prymat woli sprzedawcy w kwestii ustalenia kolejności wykonania pierwokupu przez uprawnionych (literalnie w przepisie mowa jest wprawdzie o wskazaniu uprawnionego „w pierwszej kolejności”, jednakowoż według tej samej zasady należy potraktować uprawnionego w „drugiej”, ,trzeciej” i następnej kolejności). Przy tym nie można postawić zarzutu, że interpretacja ta przełamuje jednoznaczny wynik wykładni językowej przepisu - nie jest on bowiem na tyle precyzyjny, aby powiedzieć, że zaproponowany sposób postępowania wobec uprawnionych przełamywał nie budzące wątpliwości wyniki wykładni językowej.

Inne hipotetycznie możliwe do rozważenia rozwiązania nie wydają się być adekwatne. W grę może wchodzić - przykładowo - dopuszczenie równolegle zawiadomienia wszystkich pozostałych uprawnionych po ,pierwszym” uprzednio wskazanym przez sprzedawcę, który nie wykonał swego prawa. Wówczas, w razie złożenia oświadczenia o wykonaniu prawa pierwokupu przez więcej niż jednego uprawnionego, możliwe są dla tej sytuacji dwa warianty interpretacyjne - albo nabyliby oni nieruchomość na współwłasność, albo przyjęlibyśmy zasadę ,kto pierwszy, ten lepszy" i wówczas osoba, która pierwsza złożyła oświadczenie o wykonanie prawa pierwokupu sprzedającemu, nabyłaby nieruchomość na wyłączną własność.

Pierwsza zasadnicza wątpliwość związana z zaprezentowanymi alternatywnymi sposobami postępowania $\mathrm{z}$ uprawnionymi z tytułu pierwokupu polega na tym, że rozwiązanie normatywne, w ramach którego - w tej samej grupie uprawnionych (tj. rolników indywidualnych będących właścicielami nieruchomości graniczącej ze sprzedawaną) dopuszczonoby występowanie specyficznego dualizmu w określeniu kolejności wykonania prawa pierwokupu: jedna osoba jest uprzywilejowana przez to, że wskazał ją sprzedawca, a między pozostałymi uprawnionymi w odmienny sposób rozstrzyga się kolizję prawa pierwokupu, co razi niczym nieuzasadnioną niespójnością. Jest konsekwencją zastosowania prostego wnioskowania a contrario, przebiegającego wg schematu - skoro, w kontekście więcej niż jednego uprawnionego ustawodawca stanowi o wskazaniu przez sprzedawcę rolnika, który ma wykonać prawo pierwokupu w pierwszej kolejności, i jedynie o nim, to w sposób określony w tym przepisie już kolejnych się nie wyznacza. Jednak nie można powiedzieć, aby sposób sformułowania art. 9 ust. 2 u.k.u.r. jednoznacznie przesądzał, że w tym zakresie jego regulacja ma charakter wyczerpujący, co jest wszak przesłanką ko- 
nieczną wnioskowania $a$ contrario. ${ }^{8}$ Takie postawienie sprawy ma się także nijak do zasad racjonalnego ujęcia celu instytucji prawnej - trudno wskazać jakiekolwiek racje funkcjonalne uzasadniające potraktowanie pozostałych właścicieli gruntów graniczących ze sprzedawaną nieruchomością na zupełnie innych zasadach niż pierwszego, wskazanego bezpośrednio przez sprzedawcę.

Obydwa zaproponowane rozwiązania mają jedną (i chyba jedyną) zaletę - pozwalają na relatywnie szybkie określenie czy uprawnieni korzystają z prawa pierwokupu, co jest istotne zwłaszcza w sytuacji, gdy mamy do czynienia z ich większą liczbą (nie wymaga się sukcesywnego zawiadamiania kolejnych uprawnionych w kolejności preferowanej przez sprzedawcę). Jednak obok wskazanych wyżej wspólnych dla obu wariantów obiekcji, budzą one każde z osobna następujące zastrzeżenia. Po pierwsze, nie ma racji dostatecznie uzasadniających przyjęcie, że dochodzi, w razie skorzystania z prawa pierwokupu przez kilku uprawnionych, do nabycia przez nich udziałów we współwłasności nieruchomości. Wprawdzie należy przyjąć, że pierwokup uregulowany w u.k.u.r. aktualizuje się również w przypadku udziału we własności nieruchomości, to jednak czym innym jest przyjęcie, że w razie sprzedaży własności nieruchomości może powstać stosunek współwłasności między uprzywilejowanymi pierwokupem właścicielami graniczących ze sprzedawaną nieruchomości. Sama współwłasność jest zaś postrzegana raczej jako stan tymczasowy niż definitywny i nieraz w praktyce problemy wyłaniające się na tle jej funkcjonowania stanowią zarzewie konfliktów między współwłaścicielami. W Kodeksie cywilnym wykonanie prawa pierwokupu przez kilku współwłaścicieli powoduje, że każdy z nich nabywa sprzedawany udział we współwłasności w części, ${ }^{9}$ ale kodeksowe uregulowanie ma swoją specyfiką z uwagi na to, że z definicji dotyczy sprzedaży udziału we współwłasności, a ponadto uprawnionymi są pozostali współwłaściciele prowadzący gospodarstwo na wspólnym gruncie - stąd wykonanie prawa pierwokupu przez współwłaściciela bądź kilku współwłaścicieli w takim przypadku jest działaniem korzystnym, gdyż poszerzają oni przysługujące im udziały redukując negatywne konsekwencje wiążące się z większą liczbą współwłaścicieli. ${ }^{10}$

Stosowanie zasady „,kto pierwszy, ten lepszy” również budzi zastrzeżenia. W literaturze na gruncie u.k.u.r. z 2003 r. (uregulowanego tam prawa pierwokupu dzierżawcy) oraz art. $166 \mathrm{kc}$. wyrażono opinię, że kolizja między tymi uprawnieniami powinna być rozstrzygana z uwzględnieniem reguły „kto pierwszy, ten lepszy”, zaś przyznanie preferencji któremuś z tych uprawnień byłoby przejawem arbitralnej

L. Morawski, Wykładnia w orzecznictwie sądów, Toruń 2002, s. 324-325, 329.

Por. J. Górecki, Prawo pierwokupu. Komentarz do art. 596-602 kc. i innych przepisów regulujących prawo pierwokupu, Kraków 2002, s. 198-199.

$\mathrm{Na}$ temat wątpliwości co do zastosowania art. 602 kc. i reguły nabycia nieruchomości przez uprawnionych z tytułu pierwokupu pod rządami ustawy z dnia 11 kwietnia 2003 r. zob. Z. Truszkiewicz, Przeniesienie własności..., op. cit., s. 133. 
uznaniowości, prowadzącej do dowolności i rozbieżności w podejmowanych rozstrzygnięciach. ${ }^{11}$

Takie uzasadnienie zasady „kto pierwszy, ten lepszy” nie jest satysfakcjonujące. Otóż w literaturze już podnoszono, jakkolwiek zwracając uwagę też na mankamenty innych koncepcji dotyczących rozwikłania problemu kolizji prawa pierwokupu, że przyjęcie jej prowadzić może w konsekwencji do przypadkowych rozstrzygnięć, nie mających zbyt wiele wspólnego z realizacją celów przyświecających prawodawcy ustanawiającemu prawo pierwokupu. ${ }^{12}$

Nie jest w pełni uzasadniony zarzut, jakoby przyjęcie innego rozwiązania prowadziło do uznaniowości. Jest to normalny dylemat związany z wykładnią przepisów prawa, w szczególności w przypadku odwołania się do dyrektyw funkcjonalnych w braku wyraźnego rozstrzygnięcia w warstwie językowej przepisu. Jednak w tym przypadku należy zaakcentować, że w u.k.u.r. prawodawca wyraźnie daje preferencje modelowi rozwiązania kolizji prawa pierwokupu opartemu na ustaleniu hierarchii uprawnionych, z uwagi na ustanowienie kolejności w wykonywaniu prawa pierwokupu przez wskazane w art. 9 ust. 1, 2 i 3 kategorie podmiotów. Ustanawiając w treści art. 9 ust. 2 uprzywilejowanie uprawnionego wskazanego przez sprzedającego również wprowadza się, jakkolwiek nie dość precyzyjnie uregulowany, mechanizm preferencji poszczególnych uprawnionych także wewnątrz ich poszczególnych kategorii. Ponadto można zauważyć, że rozstrzyganie według reguły „kto pierwszy, ten lepszy” jest adekwatne i nie budzi wątpliwości w innego rodzaju kontekstach regulowanych przez prawo cywilne - choćby w razie skierowania oferty zawarcia umowy do szerszego (czy też nieograniczonego) kręgu osób z zastrzeżeniem, że jej przyjęcie przez jednego z oblatów powoduje jej wygaśnięcie w stosunku do pozostałych. Mechanizm wykonania prawa pierwokupu wprawdzie wykazuje pewne podobieństwo do mechanizmu złożenia oferty i jej przyjęcia, jednak w żadnym razie nie jest z nim tożsamy. ${ }^{13}$ Wykonuje się je przez jednostronne oświadczenie woli, a samo rozwiązanie prawne dotyczące pierwokupu ustawowego nieruchomości rolnych ma w założeniu realizować cele założone przez prawodawcę, więc przepisy prawa regulujące tę materię należy interpretować z uwzględnieniem kontekstu wyznaczonego przez te cele.

Ciekawie przedstawia się problem, czy i w jaki sposób może zostać wykonane prawo pierwokupu w warunkach określonych przez art. 9 ust. 2 w sytuacji, gdy nieruchomość granicząca ze sprzedawanym gruntem jest przedmiotem współwłasno-

11 G. Bieniek, Kształtowanie ustroju rolnego, [w:] G. Bieniek, S. Rudnicki, Nieruchomości. Problematyka prawna, Warszawa 2011, s. 184.

12 Por. K. Maj, Zbieg ustawowego prawa pierwokupu, [w:] Rozprawy z prawa prywatnego i notarialnego. Księga pamiątkowa dedykowana Profesorowi Maksymilianowi Pazdanowi, A. Dańko-Roesler, A. Oleszko, R. Pastuszko (red.), Warszawa 2014, s. 215.

Por. choćby uzasadnienie postanowienia Sądu Najwyższego z dnia 9 września 2009 r. w sprawie sygn. V CSK 43/09, Lex nr 523688. 
ści. Otóż trudno znaleźć racje przemawiające za odmową przyznania prawa pierwokupu współwłaścicielom. Współwłasność jest po prostu własnością przysługującą kilku osobom, co wynika $\mathrm{z}$ art. $195 \mathrm{kc}$., jest relewantnym tytułem przy określaniu statusu danej osoby jako rolnika indywidualnego, co wynika $\mathrm{z}$ art. 3 ust. $2 \mathrm{w} \mathrm{zW}$. $\mathrm{z}$ art. 4 ust. 4 u.k.u.r., więc uzasadnione jest łączenie prawa pierwokupu z podmiotem, któremu taki tytuł prawny przysługuje. Najbardziej uzasadnione wydaje się przyjęcie, że w razie gdy przedmiotem współwłasności jest grunt graniczący ze sprzedawaną nieruchomością, w okolicznościach wskazanych w art. 9 ust. 2 u.k.u.r., przewidziane tym przepisem prawo pierwokupu przysługuje każdemu ze współwłaścicieli z osobna. Brak podstaw dla uznania, że dla wykonania prawa pierwokupu niezbędna jest jednomyślność (łączne działanie) współwłaścicieli. Nie jest to czynność z zakresu zarządu rzeczą wspólną, ale uprawnienie przysługujące rolnikom indywidualnym w związku z przysługującymi im udziałami we współwłasności gruntu graniczącego ze sprzedawaną nieruchomością.

Uważam zatem, że każdy z nich samodzielnie może wykonywać we własnym zakresie prawo pierwokupu bez wymogu łącznego współdziałania. Przy tym nie stanowiłoby problemu to, że w konkretnych okolicznościach niektórzy ze współwłaścicieli nie byliby rolnikami indywidulnymi, a inni tak. Po prostu prawo pierwokupu przysługiwałoby tylko tym, którzy spełniają kryteria określone w art. 4 u.k.u.r. $\mathrm{Z}$ uwagi jednak na to, że tacy rolnicy wywodzą swoje uprawnienia $\mathrm{z}$ wielopodmiotowego układu własnościowego (udziały łącznie składają się na „pełną” własność), to w zależności od tego, na który komponent art. 9 ust. 2 u.k.u.r. położymy nacisk: cechę ,rolnika indywidulanego" czy też na wielopodmiotowość uprawnienia do nieruchomości, możemy przyjąć następujące konstrukcje co do wykonania prawa pierwokupu.

Jeśli uznamy, że istotniejsze jest to, że mamy do czynienia z rolnikami indywidualnymi, a fakt, że przysługują im udziały we współwłasności pozostawilibyśmy na drugim planie, wówczas można bronić stanowiska, że sytuacja każdego z nich z osobna kształtuje się tak, jak innych rolników, będących wyłącznymi właścicielami gruntów graniczących ze sprzedawanym gruntem. Wobec pełnej uniformizacji statusu uprawnionych każdy z nich wykonywałby prawo pierwokupu na identycznych zasadach, w szczególności każdy musiałby być indywidualnie wskazany przez sprzedającego co do kolejności, w której (przed kim, ewentualnie po kim) może wykonać prawo pierwokupu. Wykonując je, współwłaściciel gruntu graniczącego stawałby się właścicielem wyłącznym nieruchomości, względem której wykonywał prawo pierwokupu. Negatywnym następstwem takiego potraktowania rolników indywidualnych - współwłaścicieli byłoby to, że proces zawiadamiania kolejnych uprawnionych byłby bardzo długotrwały $\mathrm{z}$ uwagi na to, że nie tylko wyłącznym właścicielom gruntów graniczących ze sprzedawanym gruntem, ale też każdemu ze 
współwłaścicieli z osobna przysługiwałby miesięczny termin na wykonanie prawa pierwokupu.

Gdyby zaś uznać, że na pierwszym planie przy określeniu statusu uprawnionych z tytułu pierwokupu rolników indywidualnych byłoby to, że są współwłaścicielami, a nie wyłącznymi właścicielami gruntu graniczącego ze sprzedawanym gruntem, wówczas konsekwentnie należałoby przyjąć, że żaden z nich z osobna nie ma w pełni samodzielnej pozycji jak inni uprawnieni będący wyłącznymi właścicielami graniczących ze sprzedawanym gruntów. Trzeba by wówczas uznać, że należałoby poinformować wszystkich współwłaścicieli danego gruntu będących rolnikami indywidualnymi równocześnie, ale każdy z nich mógłby wykonać prawo pierwokupu samodzielnie i w pełnym zakresie. Od tego, ilu współwłaścicieli zdecyduje się na wykonanie prawa pierwokupu zależy, czy korzystający z pierwokupu zostanie wyłącznym właścicielem nieruchomości, której dotyczy prawo pierwokupu (gdyby tylko on wykonał przysługujące mu uprawnienie, a pozostali współwłaściciele z niego nie skorzystali), czy też nabędzie udział we współwłasności nieruchomości, co do której wykonuje prawo pierwokupu (gdyby poza nim chociażby jeden z pozostałych współwłaścicieli również wykonał prawa pierwokupu) - art. 602 kc. Nierównorzędność poszczególnych współwłaścicieli względem wyłącznych właścicieli innych nieruchomości graniczących ze sprzedawaną nieruchomością przejawiałaby się w tym, że współwłaściciele zajmowaliby wspólnie jedno miejsce w ustalonej przez zobowiązanego kolejce osób, którym zgodnie z art. 9 ust. 2 u.k.u.r. przysługuje prawo pierwokupu, ale każdy we własnym zakresie składałby oświadczenie o wykonaniu prawa pierwokupu. Innymi słowy obowiązywałaby zasada: jedna nieruchomość granicząca - jedno miejsce w ustalonej przez sprzedającego kolejności, w której uprawnieni (każdy z osobna) mogą złożyć oświadczenie o wykonaniu prawa pierwokupu.

Opowiedzenie się za tym rozwiązaniem jest o tyle korzystne, że wobec braku w pełni autonomicznej pozycji współwłaścicieli danego gruntu skraca się czas procedury wykonania prawa pierwokupu, gdyż mimo że każdy z nich samodzielnie podejmuje decyzję o wykonaniu swojego prawa pierwokupu, to - jako że współwłaściciele ci są informowaniu o możliwości jego wykonania w tym samym czasie - powoduje to skrócenie (o ile nikt prawa pierwokupu nie wykona) okresu między zawarciem przez sprzedającego umowy zobowiązującej sprzedaży a momentem, w którym zostanie zawarta umowa o skutku rozporządzającym z osobą trzecią. Jako że zakres uprawnienia z tytułu pierwokupu nie jest zależny od wysokości udziału we własności nieruchomości, każdy ze współwłaścicieli, w razie gdyby co najmniej dwóch z nich skorzystało z pierwokupu, nabywa równy udział w nieruchomości, co do której realizują swoje uprawnienia. 


\section{REMARKS ON THE PRE - EMPTPION RIGHT OF THE OWNER \\ OF THE AGRICULTURAL PROPERTY BORDERING TO THE VENDED \\ AGRICULTURAL PROPERTY IN THE ACT ON SHAPING OF THE AGRARIAN \\ SYSTEM OF 5 AUGUST 2015}

Key words: pre - emption right, agricultural property, individual farmer

Act on the shaping of the agrarian system of 5 August 2015 provides new legal instruments limiting freedom of the contract and limiting the property right. This article deals with the proplems arising during the interpretation of the provisions of this act regarding pre - emption right of the owner of the bordering property. Individual farmer who exercises pre - emption right and acquires agricultural property is not bound to enlarge his family farm. The owner of the vended property is obliged to indicate which of his neighbours - owners of the properties bordering to his property - has the priority in pre-emption. Author also considers situation of the co-owners as the holders of the pre-emption right.

\section{Bibliografia:}

G. Bieniek, Kształtowanie ustroju rolnego, [w:] G. Bieniek, S. Rudnicki, Nieruchomości. Problematyka prawna, Warszawa 2011.

P. Czechowski, P. Wieczorkiewicz, Problemy ingerencji prawnej w swobodę obrotu nieruchomościami rolnymi w ustawie o kształtowaniu ustroju rolnego i jej wpływ na interpretację ustawodawstwa krajowego, „Studia Iuridica Agraria” 2005, t. V.

J. Górecki, Prawo pierwokupu. Komentarz do art. 596-602 kc. i innych przepisów regulujących prawo pierwokupu, Kraków 2002.

K. Maj, Zbieg ustawowego prawa pierwokupu, [w:] Rozprawy z prawa prywatnego i notarialnego. Księga pamiątkowa dedykowana Profesorowi Maksymilianowi Pazdanowi, A. Dańko-Roesler, A. Oleszko, R. Pastuszko (red.), Warszawa 2014.

L. Morawski, Wykładnia w orzecznictwie sądów, Torun 2002.

Z. Truszkiewicz, Przeniesienie własności nieruchomości rolnej w świetle ustawy o kształtowaniu ustroju rolnego (część II), ,Rejent” 2003, nr 11. 